\title{
ANTI-RADICAL ACTIVITIES OF XANTHONES AND FLAVONOIDS FROM GARCINIA SCHOMBURGKIANA
}

\author{
IMRON MEECHAI ${ }^{1,2}$, WORRAPONG PHUPONG*1,2, WARANGKANA CHUNGLOK ${ }^{3}$, PUTTINAN MEEPOWPAN 4 \\ ${ }^{1}$ School of Science, ${ }^{2}$ The Research Unit of Natural Product Utilization, ${ }^{3}$ School of Allied Health Sciences and Public Health, Walailak \\ University, Nakhon Si Thammarat, 80161, Thailand, ${ }^{4}$ Department of Chemistry, Faculty of Science, Chiang Mai University, Chiang Mai, \\ 50200, Thailand \\ Email: worrapong@gmail.com
}

Received: 02 Jun 2016 Revised and Accepted: 22 Jul 2016

\begin{abstract}
Objective: The present study aimed to isolate and identify the phytochemical constituents of Garcinia schomburgkiana branches and evaluate the antioxidant activity of the compounds.

Methods: The chromatographic and spectroscopic (UV, IR, NMR and MS) techniques were used for the isolation and elucidation of the compounds, respectively. The antioxidant activity of the isolated compounds was examined through DPPH, ABTS, nitric oxide and hydroxyl radical scavenging assay.

Results: The (-)-5,7,3',5'-tetrahydroxyflavanone (1), which was firstly found in the Garcinia species, together with kaempferol (2), (-)dihydrokaempferol (3), euxanthone (4), gentisein (5) and norathyriol (6) were isolated from G. schomburgkiana. Among the isolated compounds,
\end{abstract} compound 1 and 6 exhibited the highest potential for anti-radical activities.

Conclusion: Compound 1 could be used as the chemotaxonomic marker of G. schomburgkiana. The branches of G. schomburgkiana could be the alternative source of the antioxidants. The possible inhibitory mechanisms were proposed through the action of electron transfer, chelation, and nitrosylation.

Keywords: Xanthones, Flavonoids, Anti-radical activities, Garcinia schomburgkiana

(C) 2016 The Authors. Published by Innovare Academic Sciences Pvt Ltd. This is an open access article under the CC BY license (http://creativecommons. org/licenses/by/4. 0/) DOI: http://dx.doi.org/10.22159/ijpps.2016v8i9.13213

\section{INTRODUCTION}

In Thailand, there are 29 species of the genus Garcinia, belonging to the family Clusiaceae. A variety of phytochemicals, xanthone, flavonoid, phloroglucinol and triterpene, as well as pharmacological activities, anti-oxidant, anti-inflammatory, antimicrobial and anticancer, have been being studied [1]. Garcinia schomburgkiana, locally named Ma-dan, is commonly found in South-East Asia. Its fruits, leaves and roots have been traditionally used as a cough and diabetes treatment [2]. The wood, stem and bark of $G$. schomburgkiana were studied on the chemical constituents and their cytotoxicity. They revealed the presence of xanthones, benzophenones, biphenyls and bioflavonoids [3-5]. Some flavonoids from the genus Garcinia such as morelloflavone and fukugeside have been used as the chemotaxonomic markers [6]. Prior to this investigation, the branch of G. schomburgkiana, however, has never been reported on the anti-radical activity. Hence, the present study was undertaken to examine the anti-radical activity and phytochemical constituents of the branch of $G$. schomburgkiana.

\section{MATERIALS AND METHODS}

\section{Plant material}

In this study, branches of G. schomburgkiana Pierre. were collected from Yan Ta Khao district, Trang Province, Thailand, in October 2013. A voucher specimen (GS-001WU) is deposited at the Research Unit of Natural Product Utilization, Walailak University, Nakhon Si Thammarat, Thailand.

\section{General experimental procedures and chemicals}

Ultraviolet (UV) spectra were obtained on a JASCO V-630 spectrophotometer. Infrared (IR) spectra were recorded with Bruker Tensor 27 spectrophotometer. HR-ESI-MS spectra were recorded on a Bruker micrOTOF-Q spectrometer. The ${ }^{1} \mathrm{H}$ and ${ }^{13} \mathrm{C}$ nuclear magnetic resonance (NMR) spectra were recorded on Bruker AV $300 \mathrm{MHz}$ and Varian Unity Inova $500 \mathrm{MHz}$ spectrometers. Column chromatography (CC) was performed on silica gel $\left(\mathrm{SiO}_{2}\right.$ Merck, 40-63 $\mu \mathrm{m}$ ) and Sephadex LH-20 (GE Healthcare). The silica gel thin-layer chromatography (TLC) $\left(\mathrm{SiO}_{2}\right.$, Merck, $\left.60 \mathrm{~F}_{254}\right)$ was used for analysis and the spots were visualized under the UV light at 254 or $366 \mathrm{~nm}$ and stained with $p$-anisaldehyde solution in $2 \%$ $\mathrm{H}_{2} \mathrm{SO}_{4}$ /EtOH. All solvents were distilled at their boiling point ranges prior to use. Sodium nitroprusside dehydrates (Loba Chemie), $\mathrm{N}-1$ naphthyl ethylene diamine dihydrochloride (Loba Chemie), sulphanilamide (Carlo Erba Reagents), potassium persulphate (Ajax Finechem), salicylic acid (Ajax Finechem), 1,1-diphenyl-2picrylhydrazyl (DPPH) (Sigma-Aldrich), ascorbic acid (Carlo Erba Reagents). 2,2'-azinobis(3-ethylbenzothiazoline-6-sulfonic acid) diammonium salt (ABTS) (Sigma-Aldrich), 6-hydroxy-2,5,7,8tetramethylchroman-2-carboxylic acid (Trolox) (Sigma-Aldrich), quercetin (Sigma-Aldrich), and dimethyl sulfoxide (DMSO) (SigmaAldrich), gallic acid (Merck) and AR grade methanol (Fisher Chemicals) were used for the anti-radical activity evaluation.

\section{Extraction and isolation}

Powdered, dried branches of G. schomburgkiana (17.5 kg) were macerated twice with acetone ( $32 \mathrm{l}$ ) for $5 \mathrm{~d}$ at room temperature. The filtrate was combined and the solvent evaporation was carried out under a vacuum to give the crude extract ( $400 \mathrm{~g}$ ). The crude extract (100 g) was then subjected to a silica gel column chromatography eluted with gradient $\mathrm{CH}_{2} \mathrm{Cl}_{2}$ : $\mathrm{MeOH}$ to yield 12 fractions (A-L).

Fraction G ( $2.80 \mathrm{~g}$ ) was separated by column chromatography (silica gel, hexane: EtOAc, 70:30 to 0:100) to obtain 7 sub-fractions (G1-G7). Sub-fraction G2 (693.8 mg) was divided into 7 sub-fractions (G2AG2G) with the use of sephadex LH-20 column chromatography eluted with MeOH. Sub-fraction G2D (12.5 mg) and G2G (5.2 mg) were further separately purified through column chromatography (silica gel, $\mathrm{CH}_{2} \mathrm{Cl}_{2}$ : EtOAc 70:30) to give compound $4(7.5 \mathrm{mg}$ ) and compound 5 (2.4 mg), respectively.

Fraction $\mathrm{H}$ (6.44 g) was isolated by column chromatography (silica gel, $\mathrm{CH}_{2} \mathrm{Cl}_{2}: \mathrm{MeOH}, 100: 0$ to 80:20) to afford 8 sub-fractions (H1-H8). Sub-fraction H4 (427.7 mg) was separated by sephadex LH-20 column chromatography eluted with $50 \% \mathrm{MeOH}$ in $\mathrm{CH}_{2} \mathrm{Cl}_{2}$ to give 7 sub-fractions (H4A-H4G). Compound 2 (2.8 mg) was then isolated 
from sub-fractions $\mathrm{H} 4 \mathrm{G}$ ( $7.5 \mathrm{mg}$ ) by column chromatography (silica gel, $\left.\mathrm{CH}_{2} \mathrm{Cl}_{2}: \mathrm{MeOH}, 95: 5\right)$. Sub-fraction $\mathrm{H} 5(1.49 \mathrm{~g})$ was separated into 12 sub-fractions (H5A-H5L) by sephadex LH-20 column chromatography eluted with $50 \% \mathrm{MeOH}$ in $\mathrm{CH}_{2} \mathrm{Cl}_{2}$. Subfractions $\mathrm{H} 5 \mathrm{H}(39.4 \mathrm{mg})$ and $\mathrm{H} 5 \mathrm{I}(70.4 \mathrm{mg})$ were separately subjected to column chromatography (silica gel, $\mathrm{CH}_{2} \mathrm{Cl}_{2}: \mathrm{MeOH}, 95: 5$ ) to provide compound $3(12.6 \mathrm{mg})$ and compound $1(3.5 \mathrm{mg})$, respectively.

Fraction I $(8.67$ g) was purified by silica gel column chromatography with the gradient solvent system $\left(\mathrm{CH}_{2} \mathrm{Cl}_{2}: \mathrm{MeOH}\right.$, $95: 5$ to $70: 30$ ) to afford 8 sub-fractions (I1-I8). Sub-fraction I4 $(625.0 \mathrm{mg})$ was subjected to sephadex LH-20 column chromatography eluted with $\mathrm{MeOH}$ to obtain 12 sub-fractions (I4A-I4L). Compound $6(5.1 \mathrm{mg})$ was from the purification of subfraction I4I (116.7 mg) through sephadex LH-20 column chromatography $(100 \% \mathrm{MeOH})$ and silica gel column chromatography $\left(\mathrm{CH}_{2} \mathrm{Cl}_{2}: \mathrm{MeOH} 90: 10\right)$ successively.

\section{Antiradical activity assay}

\section{The diphenyl-2-picrylhydrazyl (DPPH) radical scavenging assay}

The DPPH radical scavenging was determined using the method described by Zongo et al. and Gogoi et al. [7, 8]. Ascorbic acid was used as the standard. Briefly, the $100 \mu \mathrm{l}$ of the extracts or standard solution in DMSO (various concentrations: $\mu \mathrm{g} / \mathrm{ml}$ ) and $100 \mu \mathrm{l}$ of the DPPH-radical $(100 \mu \mathrm{g} / \mathrm{ml}$ in methanol) were mixed. After 15 min at room temperature in the dark, the absorbance of the mixture was measured at $517 \mathrm{~nm}$. The data were expressed as the half maximal radical scavenging concentration $\left(\mathrm{SC}_{50}\right)$. The equation 1 below was used to calculate the percentage of DPPHradical scavenging.

$\%$ Radical scavenging activity $=\left[1-\left(\mathrm{A}_{\text {sample }} / \mathrm{A}_{\text {control }}\right)\right] \times 100$

Where, $\mathrm{A}_{\text {sample: }}$ The absorbance of the extracts or standards mixed with DPPH A control: The absorbance of the DMSO mixed with DPPH

The 2,2'-azinobis(3-ethylbenzothiazoline-6-sulfonic acid) diammonium salt (ABTS) cation radical scavenging assay

The ABTS cation radical scavenging was performed according to Re et al. [9] with slight modification. Trolox was used as the standard. Briefly, the ABTS radical cation was produced by the reaction of 7 mmol ABTS solution in DI water with $2.45 \mathrm{mmol} \mathrm{K}_{2} \mathrm{~S}_{2} \mathrm{O}_{8}$ in DI water. After the mixture was stored in the dark at $4{ }^{\circ} \mathrm{C}$ for $12-16 \mathrm{~h}$, the absorbance of the mixture (ABTS cation radical) was adjusted to $0.70 \pm 0.02$ at $734 \mathrm{~nm}$ by diluting with DI water. The $20 \mu \mathrm{l}$ of the extracts or standard solution in DMSO (various concentrations: $\mu \mathrm{g} / \mathrm{ml}$ ) was mixed with $180 \mu \mathrm{l}$ of ABTS cation radical. After 3 min at room temperature, the absorbance was measured at $734 \mathrm{~nm}$. The data were expressed as the half maximal radical scavenging concentration $\left(\mathrm{SC}_{50}\right)$. To calculate the percentage of ABTS cation radical scavenging, equation 2 below was used.

$\%$ Radical scavenging activity $=\left[1-\left(\mathrm{A}_{\text {sample }} / \mathrm{A}_{\text {control }}\right)\right] \times 100$

Where, $A_{\text {sample: }}$ The absorbance of the extracts or standards mixed with ABTS+* Acontrol: The absorbance of the DMSO mixed with ABTS+.

\section{The nitric oxide scavenging assay}

This nitric oxide scavenging activity was estimated according to the method of Harput et al., Ho et al. and Krishnaveni [10-12]. Vitamin C and quercetin were used as the standards. Briefly, $50 \mu \mathrm{l}$ of the extracts with varying concentrations $(\mu \mathrm{g} / \mathrm{ml})$ in DMSO and $50 \mu \mathrm{l}$ of $10 \mathrm{mmol}$ sodium nitroprusside in phosphate buffer saline (PBS), $\mathrm{pH}$ 7.4, were mixed. After incubation at room temperature for $150 \mathrm{~min}$ under the light condition, $100 \mu \mathrm{l}$ of Griess reagent (1\% sulfanilamide and $0.1 \% N$-(1-Naphthyl) ethylenediamine dihydrochloride in $2.5 \%$ $\mathrm{H}_{3} \mathrm{PO}_{4}$ ) was added. After $10 \mathrm{~min}$ at room temperature, the absorbance was recorded at $577 \mathrm{~nm}$. The percentage of nitric oxide scavenging was calculated through equation 3 below. The data were represented as the half maximal radical scavenging concentration $\left(\mathrm{SC}_{50}\right)$. $\begin{aligned} \% \text { NO-scavenging activity }= & {\left[1-\left(A_{\text {sample }}-A_{\text {sample blank }} / A_{\text {control }}-A_{\text {control blank }}\right)\right] } \\ & \times 100 \ldots \ldots .(3)\end{aligned}$

Where, $\left(A_{\text {sample }}-A_{\text {sample blank }}\right)$ : The difference in the absorbance of the extracts or standards, with or without sodium nitroprusside $\left(\mathrm{A}_{\text {control- }}\right.$ Acontrol blank): The difference in the absorbance of DMSO, with or without sodium nitroprusside

\section{The hydroxyl radical scavenging assay}

The hydroxyl radical scavenging activity was carried out according to Omwamba et al. [13] With slight modification. Trolox and gallic acid were used as the standards. Briefly, $50 \mu \mathrm{l}$ of the extracts with various concentrations in DMSO $(\mu \mathrm{g} / \mathrm{ml}), 25 \mu \mathrm{l}$ of $\mathrm{FeSO}_{4} \cdot 7 \mathrm{H}_{2} \mathrm{O}(8$ mmol), $35 \mu \mathrm{l}$ of salicylic acid $(5.7 \mathrm{mmol})$ and $40 \mu \mathrm{l}$ of $\mathrm{H}_{2} \mathrm{O}_{2}(6 \mathrm{mmol})$ were mixed. After incubation at $37^{\circ} \mathrm{C}$ for $30 \mathrm{~min}$, the absorbance was measured at $562 \mathrm{~nm}$. Equation 4 below was used to calculate the percentage of nitric oxide scavenging and the results were expressed as the half maximal radical scavenging concentration $\left(\mathrm{SC}_{50}\right)$.

$$
\begin{aligned}
\% \text { OH-scavenging activity } & =\left[1-\left(\mathrm{A}_{\text {sample }}-\mathrm{A}_{\text {sample blank }} / \mathrm{A}_{\text {control }}-\mathrm{A}_{\text {control blank }}\right)\right] \\
& \mathrm{x} 100 \ldots \ldots . . .(4)
\end{aligned}
$$

Where, $\left(A_{\text {sample }}-A_{\text {sample blank }}\right)$ : The difference in the absorbance of the extracts or standards, with or without salicylic acid. (Acontrol- $A_{\text {control }}$ blank): The difference in the absorbance of DMSO, with or without salicylic acid

\section{Statistical analysis}

All analyses were tested in triplicate and represented as the means \pm standard deviation (SD).

\section{RESULTS}

Having been dried and powdered, branches of G. schomburgkiana were macerated with acetone. The crude acetone extract, then, was subjected to a multi-step chromatographic purification to obtain (-)$5,7,3^{\prime}, 5^{\prime}$-tetrahydroxyflavanone (1) [6, 14], kaempferol (2) [15], (-)dihydrokaempferol (3) [16], euxanthone (4) [17], gentisein (5) [18] and norathyriol (6) [19] (fig. 1). Characteristics of these chemical structures were interpreted through the analysis of the spectroscopic data (UV, IR, NMR and MS) and the comparison with the literature.<smiles>COC(=O)C1CC(c2cc(O)[c-]c(O)c2)Oc2cc(O)cc(O)c21</smiles><smiles>O=C1c2c(O)cc(O)cc2OC(c2ccc(O)cc2)C1O</smiles><smiles></smiles>

4<smiles>Cc1ccc2oc3cccc(O)c3c(=O)c2c1</smiles>

5<smiles>O=c1c2cc(O)c(O)cc2oc2c(O)cc(O)cc12</smiles>

6

Fig. 1: Structures of the compounds isolated from G. schomburgkiana 
Compound 1 was obtained as light yellow powder; UV $\lambda_{\max }$ $(\mathrm{MeOH}): 326,287$ and $205 \mathrm{~nm}$. IR $v_{\max }$ (neat):3379, 3256, 1637, 1453, 1272, 1163, 1089 and $819 \mathrm{~cm}^{-1}$; ${ }^{1} \mathrm{H}-\mathrm{NMR} \delta(300 \mathrm{MHz}$ methanol- $\left.d_{4}\right): 6.93\left(1 \mathrm{H}, \mathrm{s}, \mathrm{H}-4^{\prime}\right), 6.80\left(2 \mathrm{H}, \mathrm{s}, \mathrm{H}-2^{\prime}\right.$ and $\left.\mathrm{H}-6^{\prime}\right), 5.91(1 \mathrm{H}$, $\mathrm{d}, J=2.1 \mathrm{~Hz}, \mathrm{H}-8), 5.88(1 \mathrm{H}, \mathrm{d}, J=2.1 \mathrm{~Hz}, \mathrm{H}-6), 5.29(1 \mathrm{H}, \mathrm{dd}, J=12.6$ $\mathrm{Hz}, 3.0 \mathrm{~Hz}, \mathrm{H}-2), 3.08(1 \mathrm{H}, \mathrm{dd}, J=17.1 \mathrm{~Hz}, 12.9 \mathrm{~Hz}, \mathrm{H}-3 \mathrm{a})$ and 2.70 $(1 \mathrm{H}, \mathrm{dd}, J=17.1 \mathrm{~Hz}, 3.0 \mathrm{~Hz}, \mathrm{H}-3 \mathrm{~b}) ;{ }^{13} \mathrm{C}-\mathrm{NMR} \delta(75 \mathrm{MHz}$, methanol$d_{4}$ ):196.2 (C-4), 167.1 (C-7), 164.0 (C-8a), 163.4 (C-5), 145.4 (C-3' or C-5'), 145.1 (C-5' or C-3'), 130.4 (C-1'), 117.8 (C-4'), 114.8 (C-6'), 113.3 (C-2'), 101.9 (C-4a), 95.6 (C-6), 94.8 (C-8), 79.8 (C-2) and 42.7 (C-3); $\mathrm{C}_{15} \mathrm{H}_{12} \mathrm{O}_{6}$, HR-ESI-MS $\mathrm{m} / \mathrm{z} 311.0526 \quad[\mathrm{M}+\mathrm{Na}]^{+}$(calcd. for $\mathrm{C}_{15} \mathrm{H}_{12} \mathrm{O}_{6} \mathrm{Na}$ 311.0531).

Compound 2 was obtained as yellow powder; UV $\lambda_{\max }(\mathrm{MeOH}): 371$, 266 and $205 \mathrm{~nm}$; IR $v_{\max }$ (neat):3356, 1612, 1509, 1381, 1312, 1176 and $818 \mathrm{~cm}^{-1} ;{ }^{1} \mathrm{H}-\mathrm{NMR} \delta\left(300 \mathrm{MHz}\right.$, methanol- $\left.d_{4}\right): 8.10(2 \mathrm{H}, \mathrm{d}, J=8.7$ $\mathrm{Hz}, \mathrm{H}-2^{\prime}$ and $\left.\mathrm{H}-6^{\prime}\right), 6.92\left(2 \mathrm{H}, \mathrm{d}, J=8.7 \mathrm{~Hz}, \mathrm{H}-3^{\prime}\right.$ and $\left.\mathrm{H}-5^{\prime}\right), 6.40(1 \mathrm{H}, \mathrm{s}$, H-8) and 6.19 (1H, s, H-6); ${ }^{13}$ C-NMR $\delta\left(75 \mathrm{MHz}\right.$, methanol- $\left.d_{4}\right): 175.9$ (C-4), 164.3 (C-7), 159.1 (C-4'), 156.8 (C-8a), 161.1 (C-5), 146.6 (C2), 135.7 (C-3), 129.2 (C-2' and C-6'), 122.3 (C-1'), 114.9 (C-3' and C$5^{\prime}$ ),103.1 (C-4a), 97.9 (C-6) and $93.1(\mathrm{C}-8)$; $\mathrm{C}_{15} \mathrm{H}_{10} \mathrm{O}_{6}$, HR-ESI-MS $\mathrm{m} / \mathrm{z}$ $287.0550[\mathrm{M}+\mathrm{H}]^{+}$(calcd. for $\mathrm{C}_{15} \mathrm{H}_{11} \mathrm{O}_{6}$ 287.0556).

Compound 3 was obtained as light yellow powder; UV $\lambda_{\max }(\mathrm{MeOH}): 329$, 291 and $215 \mathrm{~nm}$; IR $v_{\max }$ (neat):3245, 1638, 1458, 1362, 1233, 1164, 1088 and $833 \mathrm{~cm}^{-1} ;{ }^{1} \mathrm{H}-\mathrm{NMR} \delta\left(300 \mathrm{MHz}\right.$, methanol- $\left.d_{4}\right): 7.36(2 \mathrm{H}, \mathrm{d}, J=8.7$ $\mathrm{Hz}, \mathrm{H}-2^{\prime}$ and $\left.\mathrm{H}-6^{\prime}\right), 6.84\left(2 \mathrm{H}, \mathrm{d}, J=8.7 \mathrm{~Hz}, \mathrm{H}-3^{\prime}\right.$ and $\left.\mathrm{H}-5^{\prime}\right), 5.93(1 \mathrm{H}, \mathrm{d}, J$ $=2.1 \mathrm{~Hz}, \mathrm{H}-8), 5.84(1 \mathrm{H}, \mathrm{d}, J=2.1 \mathrm{~Hz}, \mathrm{H}-6), 4.98(1 \mathrm{H}, \mathrm{d}, J=11.4 \mathrm{~Hz}, \mathrm{H}-2)$ and $4.55(1 \mathrm{H}, \mathrm{d}, J=11.4 \mathrm{~Hz}, \mathrm{H}-3)$; ${ }^{13} \mathrm{C}-\mathrm{NMR} \delta\left(75 \mathrm{MHz}\right.$, methanol- $\left.d_{4}\right): 197.0$ (C4), 167.4 (C-7), 163.9 (C-8a), 163.1 (C-5), 157.8 (C-4'), 128.9 (C-2' and C6'), $122.3\left(\mathrm{C}-1^{\prime}\right), 114.7$ (C-3' and C-5'), 100.4 (C-4a), 95.9 (C-6), 94.9 (C8), 85.5 (C-2) and $72.2(\mathrm{C}-3) ; \mathrm{C}_{15} \mathrm{H}_{12} \mathrm{O}_{6}$, HR-ESI-MS $\mathrm{m} / \mathrm{z} 311.0526$ $[\mathrm{M}+\mathrm{Na}]^{+}$(calcd. for $\mathrm{C}_{15} \mathrm{H}_{12} \mathrm{O}_{6} \mathrm{Na} 311.0531$ ).

Compound 4 was obtained as yellow needles; UV $\lambda_{\max }(\mathrm{MeOH}): 383$, 314, 260, 235 and $204 \mathrm{~nm}$; IR $v_{\max }$ (neat):3385, 1643, 1607, 1579, 1479, 1221, 1161 and $818 \mathrm{~cm}^{-1}$; ${ }^{1} \mathrm{H}-\mathrm{NMR} \delta(500 \mathrm{MHz}$, methanol- $\left.d_{4}\right): 7.60(1 \mathrm{H}, \mathrm{t}, J=8.5 \mathrm{~Hz}, \mathrm{H}-3), 7.50(1 \mathrm{H}, \mathrm{d}, J=3.0 \mathrm{~Hz}, \mathrm{H}-8), 7.41(1 \mathrm{H}, \mathrm{d}, J$ $=9.0 \mathrm{~Hz}, \mathrm{H}-5), 7.24(1 \mathrm{H}, \mathrm{dd}, J=9.0,3.0 \mathrm{~Hz}, \mathrm{H}-6), 6.92(1 \mathrm{H}, \mathrm{dd}, J=8.5,0.5$ $\mathrm{Hz}, \mathrm{H}-4)$, and $6.71(1 \mathrm{H}, \mathrm{dd}, J=8.5,0.5 \mathrm{~Hz}, \mathrm{H}-2) ;{ }^{13} \mathrm{C}-\mathrm{NMR} \delta(125 \mathrm{MHz}$, methanol- $d_{4}$ ):183.5 (C-9), 162.8 (C-1), 157.8 (C-7), 155.5 (C-4a), 151.4 (C-10a), 137.8 (C-3), 126.3 (C-6), 122.1 (C-8a), 120.3 (C-5), 110.6 (C2), 109.4 (C-4), 109.2 (C-8) and 108.0 (C-9a); $\mathrm{C}_{13} \mathrm{H}_{8} \mathrm{O}_{4}$, HR-ESI-MS $\mathrm{m} / \mathrm{z}$ $251.0315[\mathrm{M}+\mathrm{Na}]^{+}$(calcd. for $\left.\mathrm{C}_{13} \mathrm{H}_{8} \mathrm{O}_{4} \mathrm{Na} 251.0320\right)$.

Compound 5 was obtained as yellow needles; UV $\lambda_{\max }(\mathrm{MeOH}): 373$, 308, 258, 235 and $204 \mathrm{~nm}$; IR $v_{\max }$ (neat):3286, 1660, 1622, 1586, 1482, 1240, 1149 and $821 \mathrm{~cm}^{-1} ;{ }^{1} \mathrm{H}-\mathrm{NMR} \delta(500 \mathrm{MHz}$, methanol$\left.d_{4}\right): 7.47(1 \mathrm{H}, \mathrm{d}, J=3.0 \mathrm{~Hz}, \mathrm{H}-8), 7.34(1 \mathrm{H}, \mathrm{d}, J=9.0 \mathrm{~Hz}, \mathrm{H}-5), 7.23(1 \mathrm{H}$, $\mathrm{dd}, J=9.0,3.0 \mathrm{~Hz}, \mathrm{H}-6), 6.29(1 \mathrm{H}, \mathrm{d}, J=1.8 \mathrm{~Hz}, \mathrm{H}-4)$, and $6.15(1 \mathrm{H}, \mathrm{d}, J$ $=2.0 \mathrm{~Hz}, \mathrm{H}-2)$; ${ }^{13} \mathrm{C}-\mathrm{NMR} \delta\left(125 \mathrm{MHz}\right.$, methanol- $\left.d_{4}\right): 181.7$ (C-9), 167.7 (C-3), 164.6 (C-1), 159.6 (C-4a), 155.2 (C-7), 151.2 (C-10a), 125.2 (C6), 122.2 (C-8a), 119.7 (C-5), 109.4 (C-8), 103.5 (C-9a), 99.0 (C-2) and 94.9 (C-4); $\mathrm{C}_{13} \mathrm{H}_{8} \mathrm{O}_{5}$, HR-ESI-MS $m / z 245.0444$ [M+H] ${ }^{+}$(calcd. for $\mathrm{C}_{13} \mathrm{H}_{9} \mathrm{O}_{5} 245.0450$ ).

Compound 6 was obtained as yellow-brown needles; UV $\lambda_{\max }$ (MeOH):370, 312, 254, 237 and $206 \mathrm{~nm}$; IR $v_{\max }$ (neat):3222, 1656, $1614,1514,1491,1443,1297,1183$, and $824 \mathrm{~cm}^{-1} ;{ }^{1} \mathrm{H}-\mathrm{NMR} \delta(300$ MHz, methanol- $\left.d_{4}\right): 7.44(1 \mathrm{H}, \mathrm{s}, \mathrm{H}-8), 6.82(1 \mathrm{H}, \mathrm{s}, \mathrm{H}-5), 6.29(1 \mathrm{H}, \mathrm{d}, J$ $=1.8 \mathrm{~Hz}, \mathrm{H}-4)$, and $6.15(1 \mathrm{H}, \mathrm{d}, J=2.0 \mathrm{~Hz}, \mathrm{H}-2) ;{ }^{13} \mathrm{C}-\mathrm{NMR} \delta(75 \mathrm{MHz}$, methanol- $d_{4}$ ):179.7 (C-9), 164.8 (C-3), 163.0 (C-1), 158.0 (C-4a), 153.8 (C-7), 151.8 (C-10a), 143.4 (C-6), 112.5 (C-8a), 107.8 (C-5), 102.1 (C-8), 101.9 (C-9a), 97.3 (C-2) and 93.2 (C-4); $\mathrm{C}_{13} \mathrm{H}_{8} \mathrm{O}_{6}$, HR-ESIMS $m / z 261.0394[\mathrm{M}+\mathrm{H}]^{+}$(calcd. for $\mathrm{C}_{13} \mathrm{H}_{9} \mathrm{O}_{6} 261.0399$ ).

In order to evaluate the anti-radical activities, DPPH, ABTS cation and hydroxyl radical scavenging assay and nitric oxide scavenging assay were applied and the results were reported in table 1 . The compound 6, exhibited the highest capacities against DPPH, ABTS cation, and hydroxyl radical with $\mathrm{SC}_{50} 43.29,69.12$ and 477.16 $\mu \mathrm{g} / \mathrm{ml}$, respectively. Among isolated compounds, (-)-5,7,3', $5^{\prime}-$ tetrahydroxyflavanone (1) exhibited the best nitric oxide scavenging activity with $\mathrm{SC}_{50} 905.29 \mu \mathrm{g} / \mathrm{ml}$.

Table 1: Antiradical activities of compounds 1-6

\begin{tabular}{|c|c|c|c|c|}
\hline \multirow[t]{2}{*}{ Compound } & DPPH & ABTS & Nitric oxide & Hydroxyl radical \\
\hline & $\mathrm{SC}_{50}(\mu \mathrm{g} / \mathrm{ml} \pm \mathrm{SD})$ & $\mathrm{SC}_{50}(\mu \mathrm{g} / \mathrm{ml} \pm \mathrm{SD})$ & $\mathrm{SC}_{50}(\mu \mathrm{g} / \mathrm{ml} \pm \mathrm{SD})$ & $\mathrm{SC}_{50}(\mu \mathrm{g} / \mathrm{ml} \pm \mathrm{SD})$ \\
\hline 1 & $96.66 \pm 2.28$ & $224.76 \pm 0.88$ & $905.29 \pm 7.06$ & $>1,000$ \\
\hline 2 & $95.56 \pm 1.48$ & $>250$ & $>1,000$ & $>1,000$ \\
\hline 3 & $>250$ & $>250$ & $>1,000$ & $>1,000$ \\
\hline 4 & $>250$ & $>250$ & $>1,000$ & $>1,000$ \\
\hline 5 & $>250$ & $>250$ & $>1,000$ & $>1,000$ \\
\hline 6 & $43.29 \pm 2.47$ & $69.12 \pm 0.24$ & $>1,000$ & $477.16 \pm 6.86$ \\
\hline Ascorbic acid & $14.29 \pm 0.11$ & - & $735.35 \pm 25.23$ & - \\
\hline Trolox & - & $68.67 \pm 0.40$ & - & $>1,000$ \\
\hline Quercertin & - & - & $202.41 \pm 5.38$ & - \\
\hline Gallic acid & - & - & - & $488.52 \pm 7.05$ \\
\hline
\end{tabular}

$\mathrm{SC}_{50}$ represents the half maximal radical scavenging concentration as mean values of three replicated results $\pm \mathrm{SD}$

\section{DISCUSSION}

In this phytochemical investigation of branches of $G$. schomburgkiana, the compounds 1-6 were firstly isolated from this plant. In addition, compound 1 itself was a new natural constituent from the Garcinia genus. It might be useful as the chemotaxonomic marker of $G$. schomburgkiana. For the anti-radical activity, compound 6 showed the highest activity for DPPH, ABTS cation and hydroxyl radical scavenging, possibly as a result of the readiness of the ortho-dihydroxyl group (Ring B) of compound 6 to be promptly oxidized into the corresponding more stable ortho-quinone [20] (fig.
2). According to the Fenton's reaction process, compound 6 was proposed to involve either in the reduction process of generated hydroxyl radical to become ortho-quinone [21] or directly in Fenton's reaction in which 6-OH with 7-OH groups and 1-OH with 9oxo groups chelated with iron (II) $[22,23]$ (fig. 3). While, compound 1 displayed the best activity for nitric oxide scavenging. The possible mechanism of compound 1 with nitric oxide was proposed through the nitration process at an electron rich position of an aromatic ring similar to that of tyrosine which was previously reported [24]. Consequently, compound 1 , bearing 2 hydroxyl groups, would encourage the nitration at the C-4' position as shown in fig. 4 .

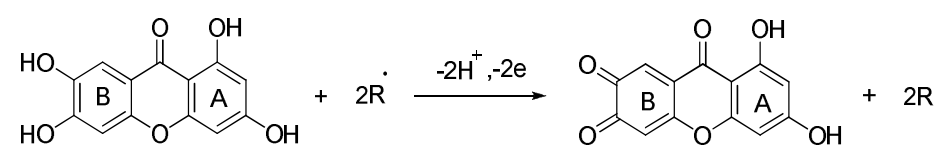




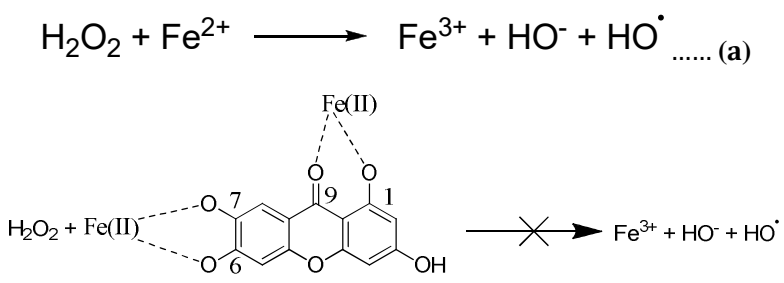

(b)

Fig. 3: (a) Fenton's reaction process and (b) The proposed mechanism of compound 6 for Fenton's reaction

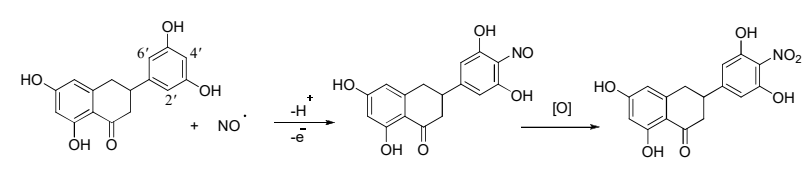

Fig. 4: The proposed mechanism of compound 1 for the nitric oxide scavenging assay

\section{CONCLUSION}

Investigation of the chemical constituents afforded six compounds, $(-)-5,7,3^{\prime}, 5^{\prime}$-tetrahydroxyflavanone (1), kaempferol (2), (-)dihydrokaempferol (3), euxanthone (4), gentisein (5) and norathyriol (6). Additionally, compound 1, which was never isolated from other Garcinia species, could be useful as the chemotaxonomic marker for the G. schomburgkiana. Compound 1 and 6 exhibited the potential for antioxidant activity. All these results indicated that the branches of $G$. schomburgkiana could be the promising alternative source of the antioxidants.

\section{ACKNOWLEDGMENT}

This work was supported by grant funds from the program Strategic Scholarships Fellowships Frontier Research Networks (Specific for Southern Region) for the Ph. D. Program Thai Doctoral degree from the Office of the Higher Education Commission, Thailand and by Walailak University Fund. The Research Unit of Natural Product Utilization, Walailak University, is also acknowledged for the facilities and technical support.

\section{CONFLICT OF INTERESTS}

The authors declare no conflict of interest

\section{REFERENCES}

1. Ritthiwigrom T, Laphookhieo S, Pyne SG. Chemical constituents and biological activities of Garcinia cowa Roxb. Maejo Int J Sci Technol 2013;7:212-31.

2. Lim TK. Edible, medicinal and non-medicinal plants. Vol. 2. New York (USA): Springer Dordrecht Heidelberg London; 2012.

3. Fun HK, Koysomboon S, Chantrapromma K, Chantrapromma S. A cocrystal of clusiacitran A, clusiacitran B, fluorinated clusiacitran A and fluorinated clusiacitran B (0.45:0.45:0.05:0.05). Acta Crystallogr 2006;E62:3228-30.

4. Häfner A, Frahm AW. Bioflavonoids from the heartwood of Garcinia schomburgkiana and their structural elucidation as atropisomers. Planta Med 1993;59:A604.

5. Mungmee C, Sitthigool S, Buakeaw A, Suttisri R. A new biphenyl and other constituents from the wood of Garcinia schomburgkiana. Nat Prod Res 2013;27:1949-55.

6. Nessa F, Ismail Z, Mohamed N, Haris MRHM. The free radicalscavenging activity of organic extract and of pure flavonoids of Blumea balsamifera DC leaves. Food Chem 2004;88:243-52.
7. Zongo C, Savadogo A, Ouattara L, Bassole IHN, Ouattara CAT, Ouattara AS, et al. Polyphenols content, antioxidant and antimicrobial activities of Ampelocissus grantii (Baker) Planch. (Vitaceae): a medicinal plant from Burkina Faso. Int J Pharmacol 2010;6:880-7.

8. Gogoi N, Gogoi A, Neog B. Free radical scavenging activities of Garcinia xanthochymus Hook. F. and Garcinia lanceaefolia Roxb. Using various in vitro assay models. Asian J Pharm Clin Res 2015;8:138-41.

9. Re R, Pellegrini N, Proteggente A, Pannala A, Yang M, RiceEvans C. Antioxidant activity applying an improved ABTS radical cation decolorization assay. Free Radical Biol Med 1999;26:1231-7.

10. Harput UŞ, Genç Y, Khan N, Saracoglu İ. Radical scavenging effects of different Veronica species. Rec Nat Prod 2011;5:1007.

11. Ho SC, Tang YL, Lin SM, Liew YF. Evaluation of peroxynitritescavenging capacities of several commonly used fresh spices. Food Chem 2010;119:1102-7.

12. Krishnaveni M. In vitro antioxidant activity of Terminalia catappa nuts. Asian J Pharm Clin Res 2014;7:33-5.

13. Omwamba M, Li F, Sun G, Hu Q. Antioxidant effect of roasted barley (Hordeum vulgare L.) grain extract towards oxidative stress in vitro and in vivo. FNS 2013;4:139-46.

14. Lee IC, Bae JS, Kim T, Kwon OJ, Kim TH. Polyphenolic constituents from the aerial parts of Thymus quinquecostatus var. japonica collected on ulleung island. J Korean Soc Appl Biol Chem 2011;54:811-6.

15. Yamauchi K, Mitsunaga T, Batubara I. Isolation, identification, and tyrosinase inhibitory activities of the extractives from Allamanda cathartica. Nat Resour 2011;2:167-72.

16. Jeon YE, Yin XF, Choi DB, Lim SS, Kang IJ, Shim JH. Inhibitory activity of aromadendrin from prickly pear (Opumtia ficusindica) root on aldose reductase and the formation of advanced glycation end products. Food Sci Biotechnol 2011;20:1283-8.

17. Mak NK, Li WK, Zhang M, Wong RNS, Tai LS, Yung KKL, et al. Effects of euxanthone on neuronal differentiation. Life Sci 2000;66:347-54.

18. Mondal M, Puranik VG, Argade NP. Facile synthesis of 1,3,7trihydroxyxanthone and Its regioselective coupling reactions with prenal: simple and efficient access to osajaxanthone and nigrolineaxanthone F. J Org Chem 2006;71:4992-5.

19. Noro $T$, Ueno A, Mizutani $M$, Hashimoto $T$, Miyase $T$, Kuroyanagi $\mathrm{M}$, et al. Inhibitors of xanthine oxidase from Athyrium mesosorum. Chem Pharm Bull 1984;32:4455-9.

20. Malhotra S, Shakya G, Kumar A, Vanhoecke BW, Cholli AL, Raj $\mathrm{HG}$, et al. Antioxidant, anti-inflammatory and antiinvasive activities of bio polyphenolics. ARKIVOC 2008;6:119-39.

21. Tirzitis G, Bartosz G. Determination of antiradical and antioxidant activity: basic principles and new insights. Acta Biochim Pol 2010;57:139-42.

22. Flora SJS. Structural, chemical and biological aspects of antioxidants for strategies against metal and metalloid exposure. Oxid Med Cell Longev 2009;2:191-206.

23. Kaiserová H, Šimůnek T, van der Vijgh WJF, Bast A, Kvasničková E. Flavonoids as protectors against doxorubicin cardiotoxicity: role of iron chelation, antioxidant activity and inhibition of carbonyl reductase. Biochim Biophys Acta 2007;1772:1065-74.

24. Gunther MR, Hsi LC, Curtis JF, Gierse JK, Marnett LJ, Eling TE, et al. Nitric oxide trapping of the tyrosyl radical of prostaglandin $\mathrm{H}$ synthase-2 leads to tyrosine imioxyl radical and nitrotyrosine formation. J Biol Chem 1997;272:17086-90.

\section{How to cite this article}

- Imron Meechai, Worrapong Phupong, Warangkana Chunglok, Puttinan Meepowpan. Antiradical activities of xanthones and flavonoids from Garcinia schomburgkiana. Int J Pharm Pharm Sci 2016;8(9):235-238. 